\title{
LAND DISPOSSESSION AND GLOBAL CRISIS: INTRODUCTION TO THE SPECIAL SECTION ON LAND RIGHTS IN THE WORLD-SYSTEM
}

\author{
Farshad Araghi \\ Department of Sociology \\ Florida Atlantic University \\ araghi@fau.edu \\ Marina Karides \\ Department of Sociology \\ Florida Atlantic University \\ mkarides@fau.edu
}

\section{INTRODUCTION}

In April 2010 the Florida Atlantic University hosted the $34^{\text {th }}$ annual conference of the Political Economy of the World-System section of the American Sociological Association. The theme of the conference was Land Rights in the World-System. The thought-provoking and wellresearched papers that were presented at the conference stimulated a lively debate and exchange of ideas that encouraged us to publish a selection of these papers that linked globalization, capital accumulation, and land rights as a special section in this issue of JWSR.

From a world-historical standpoint, the history of capitalism begins with the transformation of land rights. In one sense, the modern concept of land rights denotes the establishment of bourgeois land rights in the countryside (leading to export-led commercial agriculture) and in the city (as "real estate"). Of course, from the perspective of/within the modern world-system, it is easy to take these forms of property rights for granted and as everexisting. But this would be missing the massive social transformations that involved centuries of struggles for and against the establishment of bourgeois property rights in land and its usage. While the forms that this transformation took were complex and varied across time and space of the modern world-system, we can distinguish five of its salient features: (1) the transformation of a complex system of customary rights to land usage to legal and written titles to land ownership, (2) the transformation of the concept of property from jurisdiction over ambiguously defined areas to concretely defined (and enclosed) physical spaces, (3) the rationalization of the use of such demarcated landed property as a form of capital and at the service of "primitive" and expanded capital accumulation, (4) the increasing privatization of the earth's surface through dispossession and displacement of peasants and Indigenous populations, and (5) destruction of nonmarket access to food and self-sustenance and creation of a (mobile) global proletariat that is massively concentrated at the urban centers of the world economy (and often living a life under a regime of "forced underconsumption") (Araghi 2010a). The complex global history of this process of commodification of land rights can be divided into four historical periods: primitive accumulation, colonialism, developmentalism, and globalization. 


\section{PRIMITIVE ACCUMULATION AND LAND RIGHTS}

This period, roughly between the $15^{\text {th }}$ and the $19^{\text {th }}$ centuries, marks the emergence of bourgeois conceptions of land rights (in the senses discussed above). While the Eurocentric analyses of "primitive accumulation" always focus on the forceful seizure of land from the British yeomanry and the enclosure of the common land by the commercially-minded, wool-exporting, feudal overlords in England, a global history of primitive accumulation and the transformation of land rights will include the violent confiscation of non-European lands and resources. Specifically, global primitive accumulation included the separation of Indigenous populations from the land and the alienation of their customary (communal or tribal) rights to land usage either through massacre (white settlements) or enslavement (physical removal from ancestral or tribal land) (Araghi 2009). Thus we may symbolically use the year 1492 as an expression of two expropriating movements, one inward and one outward; that is on the one hand the beginning of the systematic expropriation of the Americas' Indigenous populations by conquest, expropriation, and settlements, and, on the other hand, racialized land seizures and population displacements within Castilian Spain (in which the thirst for land accumulation was connected with the emerging transformation of land rights in the world-system). This broad (and nonteleological) interpretation of "global primitive accumulation" links the global transformation of land rights to the rise of industrial capitalism proper in the $19^{\text {th }}$ century.

\section{CAPITALIST COLONIALISM AND LAND RIGHTS}

The $19^{\text {th }}$-century reconfiguration of the global division of labor under British hegemony around the needs of the now dominant regime of industrial capitalism led to a reorganization of land use and land rights on a global scale. Reorganizing world trade in accordance with the law of value, Great Britain and its European competitors alike embarked on a massive global land-grab in their scramble for colonies (Araghi 2003). The colonial land grabs enforced various racialized and gendered regimes of forced labor as a way of constructing export-dependent monocultures that subsidized the reproductive needs of European labor and capital (McMichael 2012). The new incentive to expropriate whole nations for the expanding accumulation of profit and power vastly transformed communal, tribal, and peasant land rights in the colonial world. At the same time, expanding monocultures compromised local food security and ecological sustainability. When the inevitable agro-ecological crises took place, famines (and a liberal preference for the "invisible hand" to guide policy) resulted in massive out-migrations that separated the direct producers from the land. The Great Irish Famine of 1845 to 1849 and the Indian famine of 1881 are cases in point (Woodham-Smith 1991; Davis 2002).

\section{LAND RIGHTS AND DEVELOPMENTALISM}

Both state socialist and pro-market developmentalisms brought major transformation of land rights via state-sponsored collectivization schemes or land reforms that laid the foundation for postwar waves of "dispossession by displacement." While the agrarian trajectories of postcolonial nation-states were diverse and had various social histories and determinants, the 


\section{JOURNAL OF WORLD-SYSTEMS RESEARCH}

postwar developmentalist period saw the simultaneous expansion and contraction of land rights for the postcolonial peasantries (Araghi 1995). On the whole, the contraction of land rights was much greater than the expansion of land rights obtained via land reforms in the Cold War context. As a consequence, a massive number of people who were involved in subsistence agriculture were expropriated and displaced. As formerly self-sufficient agricultural peoples were pushed into the centers of urban capital accumulation, a global housing crisis emerged. A massive commodification of urban housing combined a real estate and construction boom for developers and a housing question for the dispossessed or semi-dispossessed. This was followed by social struggles for land rights in cities by the new and numerous proletarian class in formation.

\section{GLOBALIZATION AND LAND RIGHTS}

"Agrarian development in reverse" has been a core component of neoliberal globalization. With respect to land rights, this period has witnessed a vast expansion of bourgeois land rights at the expense of small/partial land-holder remnants of the developmentalist era on the one hand and the rise of powerful "counter enclosure" movements on the other hand (Araghi forthcoming). Specifically with the privatization of agrarian welfare states that operated to the advantage of transnational agribusiness and capitalist farms, the relative abrogation of public land rights and displacement of the postwar era has been followed by aggressive global enclosures and massive contraction of land rights for the world's agrarian populations and absolute depeasantization on a world-scale (Araghi 2009; 2010a). Neoliberal attacks on rural and urban public land rights were based on the following developments: (1) the liberalization of land markets and total abandonment of land reforms that ostensibly proclaimed a land-to-the-tiller intention, (2) the expansion of price supports for the large agroexport corporations involved in bulk commodity production (and in recent years in biofuel), (3) drastic cuts in farm subsidies and price supports for petty commodity producers and the disengagement of both postcolonial states and the World Bank from irrigation support, (4) an aggressive expansion of the commodification of seeds and seed reproduction, (5) increasing dependence on hydrocarbon farm inputs, and (6) the promotion of agroexports modeled after the colonial division of labor discussed above (in particular, production for export of animal feed and agrofuels). Especially since the financial crisis of 2007, a "food bubble" has been in formation that is partly replacing the collapsed "housing bubble" (Araghi 2008, 2010b). Currently, a global land grab unprecedented since colonial times is underway as speculative investors - who now regard "food as gold" - are acquiring millions of hectares of land through the purchase of land in the global South (Henriques 2008). These land grabs often involve the eviction of local producers and forced expropriations under the rubric of confronting the global food and energy crises (McMichael 2011). According to the latest Oxfam study (2011), "in developing countries, as many as 227 million hectares of land - an area the size of Western Europe - has been sold or leased since 2001, mostly to international investors. The bulk of these land acquisitions has taken place over the past two years, according to ongoing research by the Land Matrix Partnership" (emphasis added).

The papers presented at the PEWS conference address many of the issues broadly outlined above. In the opening article Immanuel Wallerstein relates the emerging crisis of the world-system to the history of land rights, global ecology, group formation and social movements, and the dilemma of the global (developmentalist) left. Charles Geisler deconstructs the reemerging (neocolonial) discourse of terra nullius and land grabs in Africa. Phillip Hough 


\section{LAND DISPOSSESSION AND GLOBAL CRISIS 4}

and Jennifer Bair critically consider the link between accumulation by dispossession and the Polanyian-inspired conceptualizations of counter-movements, offering an alternative, historically specific interpretation of the rise and development of the Unidad Cafetero Nacional (UCN) movement in Colombia. Similarly, Astra Bonini emphasizes the historical specificity of the global regimes of accumulation and their trade strategies in assessing the consequences of cash crops and extractive export orientation. Ganesh K. Trichur develops an interesting challenge to the accumulation by dispossession model in his examination of China. He argues China's development unfolded on its own terms, and while land grabs did occur in China, the state selectively allowed foreign capital in its coastal zones, portending a future of more equitable land use. In his study of South Africa, Ben Scully suggests that a return to the land-labor-livelihood framework can help revive contemporary labor studies in South Africa and for our current global circumstances by knitting labor research with land rights and by recognizing households as units of resources, including wages, informal earnings, and land. In our only paper on urbanization, quite possibly an indication of the dearth of recent world-systems analyses of this process, Andrew K. Jorgenson and James Rice draw attention to the prevalence of slum dwelling and its impact on children's health. Through a panel regression analysis, Jorgenson and Rice provide one of the first empirical studies that demonstrate urban slum prevalence as a distinct and statistically significant variable for explaining a rise in child mortality rates.

The $34^{\text {th }}$ Annual PEWS conference was a pleasure to host. The papers presented in this special issue of JWSR capture, at least to some extent, the eventful and engaging discussions that occurred over the few days when PEWS colleagues met, presented, and socialized. We hope they make a contribution to the ongoing discussions and debates on this topic of vital urgency to so many people around the world. We sincerely thank the contributors of this section for their time, patience, and participation. 


\section{JOURNAL OF WORLD-SYSTEMS RESEARCH}

\section{REFERENCES}

Araghi, Farshad. 1995. "Global Depeasantization, 1945-1990."

Sociological Quarterly 36: 337-368.

. 2000. "The Great Global Enclosure of Our Times: Peasants and the Agrarian Question at the End of the Twentieth Century." In Hungry for Profit: the Agribusiness Threat to Farmers, Food, and the Environment, edited by F. Magdoff, F. H. Buttel, and J. Bellamy Foster. New York: Monthly Review Press. . 2003. "Food Regimes and the Production of Value: Some Methodological Issues." Journal of Peasant Studies 30(2): 41-70. . 2008. "Political Economy of the Financial Crisis: A World-Historical Perspective." Economic \& Political Weekly 43(45): 30-32. . 2009. "The Invisible Hand and the Visible Foot: Peasants, Dispossession and Globalization." In Peasants and Globalization: Political Economy, Rural Transformation and the Agrarian Question, edited by A. Haroon Akram-Lodhi and Cristóbal Kay. New York: Routledge. . 2010a. "Accumulation by Displacement: Global Enclosures, Food Crisis, and The Ecological Contradictions Of Capitalism." Review: A Journal of Fernand Braudel Center 34(1): 113-146. . 2010b. "The End of 'Cheap Ecology' and the Crisis of 'Long Keynesianism."” Economic \& Political Weekly 44(4): 39-41.

. Forthcoming. "Accumulation by Enclosure and the Alternatives of the CounterEnclosure Movements of Our Times."

Davis, Mike. 2002. Late Victorian Holocausts: El Niño Famines and the Making of the Third World. London: Verso.

Henriques, Diana. 2008. "Food Is Gold, So Billions Invested in Farming." New York Times, June 5.

McMichael, Philip. 2012. Development and Social Change: A Global Perspective. Thousand Oaks, CA: Pine Forge Press. . 2011. "The Food Regime in the Land Grab: Articulating 'Global Ecology' and Political Economy." Paper presented at the International Conference on Global Land Grabbing, 6-8 April, University of Sussex, Brighton, UK.

Oxfam. 2011. "Land and Power: The Growing Scandal Surrounding the New Wave of Investments in Land." Retrieved November 9, 2011 (www.oxfam.org/en/grow/policy/land)

Woodham-Smith, Cecil. 1991. The Great Hunger: Ireland 1845-1849. London: Penguin 